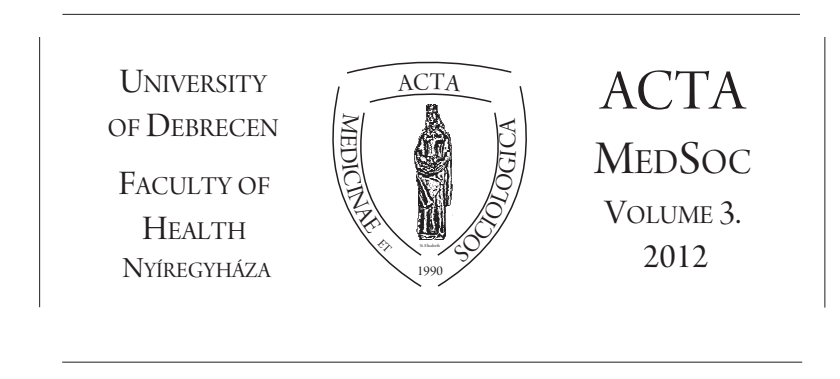

\title{
Test-Lélek koncepciók és a mögöttük álló szemléletváltás az európai filozófiában
}

\author{
Vincze Krisztián \\ Szent Atanáz Görög Katolikus Hittudományi Főiskola
}

\begin{abstract}
Body-soul conceptions and the change approach behind them in European philosophy.

This short study has the purpose to approach the question of human body and soul philosophically. The systems of philosophy shortly outline and gradually unfold the related questions and answers, so in one respect they deal with the human being appearing in the unity of body and soul, as well as the option conditions of this unity. On the other hand, we are getting to know the arguments as a direct opposite of it, on the basis of which some philosophers want to reduce bodily to spiritual or spiritual to bodily, namely the reality of our spiritual or our bodily side of human being is doubted. In this way the ideas of various experts will be shown: we are to look inside the general European mankind represented by Platoon, Aristotle and Christianity responding to the differences between them. In body and soul connection the theories of New Age thinkers will be mentioned, among which Descartes' theory stands in the centre, as the theories of the French thinker generated a lot of disputes. Following the New Age thinkers we will get to the Twentieth Century, examining the opinion of more well-known contemporary metaphysical trends which very often found their inspiration in psychology itself, and they are connected to the questions of the Twentieth Century linguistics philosophy. The last part of the study wishes to set forth what kind of changes the meaning of soul and body as a concept has gone through, how and to which direction the New Age's major science, Psychology, diverted our evolving thoughts about the duality of human nature.
\end{abstract}

Keywords: body-soul problem, dualism, monism, psychosomatic, hülémorfism

DOI: $10.19055 / \mathrm{ams} .2012 .3 / 4-5 / 5$ 


\section{A test-lélek kérdés}

Korunk egyik jellemzője az, hogy sokan szeretnek hivatkozni az ateista színezetú racionalizmusra, szkepticizmusra, a szekularizált világképre és a szaktudományos pozitivizmusra, amikor a keresztény vallás egy-egy alapvető tanítását utasítják el. Az újkor, s majd a legújabb kor emberére jellemzô az, hogy egyre radikálisabban fogalmaz évszázadok hagyományával szemben, egyre radikálisabb módon kérdójelez meg hosszú idốn keresztül egyértelmúen elfogadott igazságokat. Már a Fides et ratio enciklika felhívja figyelmüket arra, hogy a keresztény tanítás elutasítói olyan szellemi áramlatokba burkolóznak bele, mint az agnoszticizmus, relativizmus, közömbös pluralizmus, eklekticizmus, nihilizmus, pragmatizmus és a posztmodern szemlélet. Ezek lényege általában abban áll, hogy számukra nem lehetséges abszolút igazság elfogadása, szemléletükben a világ dolgainak valójában nincs értelmük, egyáltalán nincsenek alapvetô és mindenkire vonatkozó erkölcsi alapelvek, valamint nincs egyetemes tekintélye semminek és senkinek. ${ }^{1}$ A cáfolatok leginkább az Isten létére, létének bizonyíthatóságára, a vallási tanok metafizikai vetületeire vonatkoztak. Ezenfelül azonban olyan cáfolatok is hangot kapnak, melyekben nem csak kifejezetten vallási igazságokat illetnek kétellyel, hanem bennük a hagyományosnak tekintett emberkép is megrendül. Arthur Schopenhauer, mint az újkor egyik ismert kételkedője a hagyatékában megtalált egy rövid írása alapján így fogalmaz: „Isten, ha létezel, mentsd meg a sírból az én lelkem - már amennyiben van olyan!"2 Schopenhauer tehát nem csak Isten létében kételkedik, hanem az európai emberkép egyik általános koncepciójával szemben is szkeptikussá válik: az emberben csak a testit véli látni, s ennek a pusztán testi látásmódnak még sok követôje akad majd. Schopenhauert két évszázaddal elôzi meg Pascal, aki szerint az ember képtelen felfogni, hogy mi is az emberi test, még nehezebb felfognia a lélek mibenlétét, ami pedig a legnehezebb kihívást jelenti az emberi értelemnek, az annak a megfejtése, hogy hogyan is egyesülhet a test a lélekkel. ${ }^{3}$ A francia keresztény gondolkodó számára az embert alkotó titokzatos kettőség jelenti az emberi nem nagyságát, amit utókora - ahogyan azt Schopenhauer is tette - majd több alkalommal is kérdésessé tett. Vajon jogos-e bármilyen kételkedés az emberi lélek létét illetôen? Ez az a kérdés, amire persze egy keresztény gondolkodó egyértelmú nemmel válaszolna. Van azonban filozófiai szinten egy ezt megelőző kérdés, ami a keresztény világképben gondolkodók számára is érthetóbbé teszi, hogy mi alapján kételkedhetnek egyesek

\footnotetext{
${ }^{1}$ Vö. Fides et ratio, VII. fejezet, Pápai enciklika, 1998.09.14.

${ }^{2}$ KÖHLER, P.,Geh mir aus der Sonne! Anekdoten über Philosophen und andere Denker, Stuttgart 2004, 117.

3 „Látva, hogy mindent szellemból és testból rakunk össze, nem azt hinné-e bárki, hogy ez a keverék roppant érthető számunkra? Pedig éppen ezt értjük a legkevésbé. Az ember önmaga számára a természet legcsodálatosabb tárgya; mert képtelen felfogni, mi a test, még kevésbé, hogy mi a lélek, és mindennél kevésbé azt, hogy miképpen egyesülhet a test a lélekkel. Ez minden nehézségek teteje, és mégis ez maga az ember." Vö. PASCAL, B., Gondolatok, Szeged 2005, 28.
} 
az emberi lélek létében. A lélekkel kapcsolatos kételkedéseket és megvallásokat befolyásolja ugyanis az is, hogy a különbözô szaktudományok milyen újabb felfedezésekkel járultak hozzá emberi önismeretünkhöz. Ha van tehát egy elôzetes kérdés, akkor az abból fakad, hogy az egyre inkább gyarapodó pszichológiai, biológiai, neurofiziológiai ismereteink valószínúleg különböző szempontokból érkeznek el olyan fogalmakhoz, mint pl. a ,lélek”, „lelki”, ,tudat” stb. Fogalmazzuk meg ennek fényében másképpen a kérdést! Vajon a különböző filozófusok és filozófiai rendszerek minden esetben ugyanarra az emberi lélekre gondolnak-e traktátusaikban, vajon ugyanabban az értelemben beszélnek-e lélekről, amikor ezt a fogalmat használják, s ezen keresztül az emberi természet tulajdonságait próbálják megvizsgálni?

Ennek a rövid áttekintő jellegú tanulmánynak tehát az a célja, hogy a test és lélek kérdését filozófiai szempontból közelítse meg. Az egymásután röviden felvázolt filozófiai rendszerek fokozatosan bontják ki kérdéseiket és válaszaikat, s így foglalkoznak egyrészt a test és lélek egységében megjelenő emberrel, ennek az egységnek a lehetôségi feltételével. Másrészt azonban ezzel szöges ellentétben azokkal az érvekkel is megismerkedünk, amelyek alapján egyes szerzók a testit akarják lelkire vagy a lelkit testire redukálni, azaz az emberi létezésben vagy a lelki vagy a testi oldalunk realitását vonják kétségbe. Így mutatom be a különbözô szerzôk elképzeléseit: áttekintjük a hagyományosan európai emberképet, amit Platón, Arisztotelész és a kereszténység képviselt, utalva természetesen az ezek között fennálló különbségekre is. Test és lélek összefüggésében megemlítem ezt követôen az újkori gondolkodók elméleteit, amely elméletek között Descartes-é foglal el központi szerepet, hiszen a francia gondolkodó tézisei sok vitát váltottak ki. Az újkori szerzóket követve eljutunk a XX. századi, az ismertebb kortárs metafizikai áramlatok véleményéig, melyek ihletüket sokszor a pszichológiából nyerték, ugyanakkor kikerülhetetlenül érintkeztek a XX. századi nyelvfilozófia kérdésköreivel is. A tanulmány utolsó fejezete azt kívánja felmutatni, hogy időközben a lélek és test fogalmak jelentése milyen változáson esett át, s az újkori szaktudományos pszichológia milyen irányba terelte ennek megfelelően az emberi természet e kettőségéról kialakuló gondolatainkat.

\section{Platón, Arisztotelész és a keresztény tanítás}

A mindennapi beszédben és leginkább a hagyományos vallási nyelvezetben, amikor lélekrôl beszélünk, akkor a tudatos, a szellemi lélekre gondolunk. Beszélünk lelki állapotainkról, lelki tapasztalatokról, beszélünk lelkivezetésrôl is, és a lélek halhatatlansága által a túlvilági létünket is e fogalom felól közelítjük meg. Lélek alatt értjük a tudatos életünket, a belsố világunkat, a szellemi princípiumot. Ügyelnünk kell azonban arra, hogy a görög és latin kifejezések alapján lélek és szellem nem ugyanazt jelentik, nem pontosan ugyanarra a valóságra vonatkoznak. Lélek (a görög $\psi v \chi \eta ́$, a latin anima) alatt az ókori görög filozófia az életprincípiumot, az élólények éltető elvét értette, nem pedig a tiszta szellemi realitást. Használjuk a modern pszichológiában is a lélek kifejezést, de ilyenkor a pszichés élet, a pszichés történések lényegi elemére utalunk vele. Rene Descartes számára a res cogitans tel- 
jes mértékben a tudatos szférával esett egybe, ma azonban már tudjuk, hogy létezik az emberi tudattalan vagy tudatalatti pszichés élet is, amely közvetve vagy közvetlenül kihathat a tudatos pszichés életünkre. Ebból a szempontból, ami pszichés, ami a psziché alá tartozik, azt a tudattal kötik össze, a tudatoshoz sorolják.

Az ókori filozófiában lélekkel ruháztak fel minden élólényt. Lelke van eszerint a növényeknek, állatoknak és persze az embereknek is - hiszen élő mivoltuk árulkodik a bennük található életelvről, életerôrool. Ezeket a lelkeket attól függôen különböztették meg, hogy milyen képességeket adományoznak a növényi, állati és emberi létezóknek. Ezek a különbségek voltak a vegetativitás, szenzitivitás és végül az értelmes lélek, ami csak az emberi létezés sajátságos jegye. Így különül el az ember

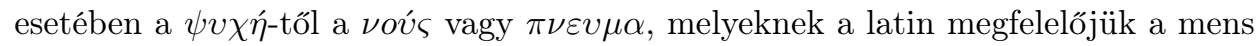
és spiritus. E fogalmak alatt azonban már egy magasabb, anyagtalan, testfeletti lét- és hatóelvet gondolt a görögség. Ebben az értelemben volt lehetséges pl. a tiszta szellemi (spiritus purus) létezésról is beszélni. Az ember esetében nem a tiszta szellemi lét az ót meghatározó létmód, hiszen ố az a létezô, akinek a lelke, a szelleme egyben a testének átlelkesítôje is; a lélek ennek értelmében tehát életelv, mely a testet kell, hogy áthassa és éltesse. Másképpen megfogalmazva: az embernek szellemi lelke van (anima intellectualis vagy anima spiritualis), melynek kettôs a funkciója: princípiuma az emberi éló testnek és princípiuma az emberi szellemi tevékenységnek.

A görögségben egyrészt találkozunk egy dualista értelmezéssel, amely Platón filozófiájában bontakozik ki. Platón ugyanis a lelket inkább tiszta szellemi létezésként érti, amelynek független preegzisztens léte van. A platóni filozófia értelmében vett lélek teljes mértékben függetlenedni tud az emberi testtől, mi több, erre kell törekednie. A test Platón szerint csak koporsó és börtön a lélek számára, amely éppen a test fizikalitása által okozott akadályok miatt nem juthat teljes ismeretre. Az emberi élet kijelölt célja így az lesz, hogy a lélek szakadjon el a testtól, és az intelligibilis létezók, az ideák szemléletére jusson el. A metafizikai dualizmus tehát az értelmezési kulcsa ennek a test-lélek együttesnek: ami testi, az az árnyék-, a látszatvilághoz tartozik, miközben a lelkiek, a lélek az örök ideavilág állampolgára.

A görögségben ott van azonban másrészt az anyag-forma szemléletmód, melyet Arisztotelész alkalmaz a test-lélek problémára is. Arisztotelész hülémorfizmusa szerint minden létezô két lételvnek, a formának és az anyagnak az összetételén keresztül nyeri el létezését. A forma mindig az, ami az önmagában meghatározatlan anyagnak struktúrát, meghatározott lényegiséget kölcsönöz. Így az ember eseté-

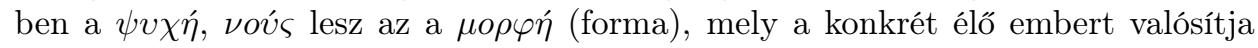
meg, amely az élettelen anyagot élettel tölti meg. Arisztotelész kijelenti, hogy az élô emberi test csakis a lélek által lehet éloo. Nincs olyan élô ember, akitôl bármilyen formában elvitatható lenne a lélek. Az ember az a létezó, aki a formálatlan, önmagában halott anyag és a formaadó lélek együttese által lesz emberré.

Megemlítjük továbbá a bibliai tanítást is, az ószövetségi írások emberképét is, amelyrôl tudnunk kell, egyáltalán nem a platóni dualizmus jegyében közelíti meg az emberi létezést. A héber nephesch szó utal a lélekre, amelyet nem a testtôl és 
testitől elkülönítve gondolt el zsidóság, hanem mint a testet éltetôt és a testnek életerôt adó valóságot látta maga elótt. Igaz, hogy az ószövetségi Szentírásból hiányzik a mélyebb filozófiai reflexió, de az egyértelmúen kiderül, hogy az emberi lelket a Biblia is, mint életelvet jelöli meg. Az újszövetségi Szentírás, az evangéliumok hoznak majd egyfajta újdonságot, mert már egyértelmúen beszélnek a test és a lélek különbségérôl, ugyanakkor a feltámadásról szóló szövegekból pedig az sejlik ki, hogy a testet a kereszténység nagyra értékeli, és az ember végérvényes stádiuma is csak a test-lélek egységében gondolható el. Pál apostolnál még élesebbek a különbségek lélek és test tekintetében, de a bibliai fogalomtárban e két fogalomnak immár természetfeletti, üdvtörténeti jelentése is van. Így a $\sigma \alpha \alpha \beta$ (hús/test) a bukott, búnös emberi természetre utal, amíg a $\pi \nu \varepsilon v \mu \alpha$ lesz az új, megváltott élet princípiuma; sót a $\pi \nu \varepsilon v \mu \alpha$ utal ezenfelül az Isten Lelkére is, akit ajándékba kapunk, és aki bennünk is lakik.

Már az eddigiek alapján is észrevehetjük, hogy test és lélek tekintetében lehet dualista és nem-dualista módon is gondolkodni. Szent Ágoston kereszténységében a dualista felfogás domborodik ki, melyben test és lélek egymásnak feszülve egymás ellen kell, hogy küzdjenek. A skolasztika idejére azonban a platóni dualista behatást inkább az arisztotelészi látásmódok fogják felváltani. Már Albertus Magnus írásaiban úgy szerepel a lélek, mint "forma corporis", bár még ezt a megfogalmazást bizonyos fenntartásokkal kezeli a szerzô, hiszen veszélyeztetettnek túnik ebben a szellemi lélek transzcendenciája, az anyagtól való belsố függetlensége és a testi halál után való továbbélte. Albertus Magnus tanítványa, Aquinói Szent Tamás lesz az, aki majd erre megnyugtató választ és megoldást tud adni azáltal, hogy különbséget tesz olyan lényegi formák között, melyek önmagukban szubzisztálnak és amelyek önmagukban nem képesek szubzisztálni. Az emberi lélekról azt állapítja meg Szent Tamás, hogy "forma corporis", de mivel in se subsistit, így az anyagi test nélkül is létképes, közben pedig az anyagi testben az anyagi szubsztrátumtól belsôleg független szellemi aktusokra képes. A lélek tehát a testtel együtt alkotja az egy és ugyanazon embert, de szellemi lényege felülemelkedik az élő testben betöltött funkcióján. Az V. Lateráni zsinaton már az arisztotelészi-tomista test-lélek koncepció adja a hivatalos egyházi tanítást.

\section{Szubsztanciadualizmus és szubsztanciamonizmus}

A kortárs metafizika a test és lélek koncepciókat tekintve két nagy csoportot különböztet meg. Egyrészt beszél szubsztanciamonizmusról, másrészt pedig szubsztanciadualizmusról. A szubsztanciadualizmus szerint az emberi elme alapvetôen különbözik az emberi testtől. A mentális szubsztancia az emberi elme, aminek egyetlen egy fizikai tulajdonsága sincs, tehát nem azonosítható semmiképpen sem fizikai dolgokkal. Mivel szubsztancia, így képes minden fizikai dologtól függetlenül létezni - ahogyan ezt az arisztotelészi szubsztancia fogalom megköveteli. Ha azt mondjuk, hogy egy ember mentális állapotai változnak, azaz gondolatok, érzelmek, érzetek váltják egymást benne, akkor ezek a beállt változások mind az emberi 
mentális szubsztancia változásai. Ezzel áll szemben a szubsztanciamonizmus elmélete, amely szerint nem kell megkülönböztetni két különbözô típusú szubsztanciát a világban, hiszen csak egyetlen egy létezik, amit sok esetben "félre ismertek" és elhibázott módon más természetúként jelöltek meg. A monizmuson belül a két nagy áramlat az idealizmus - amely szerint a világ igazi alkotórésze mentális, szellemi természetû. A másik monista elképzelés a fizikalizmus vagy materializmus, amely a világban csak az anyagi létezést ismeri el. Ez az a két nagy áramlat, amelyet különböző filozófiák képviselnek, s amelyek mellett érveiket felsorakoztatják. E két nagy áramlat főbb képviselőit és gondolatmenetüket szeretném áttekinteni a következô oldalakon.

\subsection{Idealista szubsztanciamonizmus}

A szubsztanciamonizmuson belüli felfogásoknak az a lényege, hogy vitatják a testnek és léleknek az egymástól eltérô szubsztancialitását, ehelyett inkább egyik valóságot próbálják meg a másikra redukálni. Az idealista elméletek arról akarnak meggyőzni bennünket, hogy minden, ami a világban létezik és megtapasztalható, az szellemiból eredeztethető, szellemi lényegre vezethetô vissza, még akkor is, ha esetleg az érzékeink által, azaz anyagiságukban fedezzük fel azokat. A XVII. sz.-ban élt Benedictus de Spinoza, akinek filozófiája sok ihletet nyert a descartes-i gondolatokból, ugyanakkor azonban Descartes-ot cáfolva a panteizmusra hajló gondolkodó szerint immár nem háromféle szubsztancia létezik a világmindenségben (Isten, kiterjedés, gondolkodás), hanem egyetlen egy: az isteni szubsztancia. Ennek az egyetlen szubsztanciának pedig a kiterjedés és gondolkodás lesz a két attribútuma. Ily módon egy ember tulajdonképpen egy és ugyanazon valóság két dimenziójának egy módusza; azaz rendelkezik anyagi-fizikai tulajdonságokkal és ezzel egy időben pszichés-szellemi megnyilvánulásai is vannak. Szubsztancia alatt Spinoza azt érti, ami önmagában és önmaga által érthető, amelynek fogalmát úgy alkothatjuk meg, hogy eközben nem szorulunk rá más dolgok fogalmaira - ennek a feltételnek azonban csakis Isten felel meg. Természetesen e szigorú szubsztancia fogalom következménye a modernkori panteizmus, amiben Isten és világ, Isten és ember közötti különbség eltűnik. Az emberi lélekről a következô módon szól Spinoza: "Az emberi lélek az Isten végtelen értelmének egy része; így ha azt mondjuk, hogy az emberi lélek ezt vagy azt észleli, akkor nem mondunk mást, minthogy Isten az - amennyiben az emberi lélek lényegét ô adja -, aki ezt vagy azt észleli."4

Szellemi monizmusra eklatáns példa még Hegel filozófiája, hiszen abban minden történés a szellem történése. A szellem önmagától elidegenedik, majd elidegenedettségében önmagához viszonyul, és legvégül visszatalál majd önmagához. A szellem kibontakozásának egyik stádiuma az anyag és az anyagiság, melynek a szellemibe kell beletorkollania. ${ }^{5}$ A német idealista gondolkodó szerint a legmaga-

\footnotetext{
${ }^{4}$ Vö. SPINOZA, B., Etika, Budapest 1979, II. rész, 11. tétel.

5"'Ein Baum, ein Mensch, ein Staat, sie alle sind mehr oder minder wirklich, und zwar im Maße dessen, wie sie dem Begriff des Baumes, des Menschen, des Staates entsprechen, oder Hegelisch gesprochen, wie dieser in ihnen wirksam ist. Das aber besagt: Der Begriff ist es, der allem
} 
sabb rendú realitások természetesen a szellemi, az eszmei realitások. Az érzékileg megtapasztalható dolgok is csak oly mértékben felelnek meg önmaguknak, amely mértékben megfelelnek az óket megjelölő fogalmaknak. A világ fontos tulajdonsága pedig nem csak az, hogy az eszmeiból származik, hanem hogy az eszmeiben is fog beteljesedni! „Az igaz az egész. Az egész pedig csak a fejlődése által kiteljesülő lényeg." ${ }^{\circ}$ Az Abszolútumnak a hegeli filozófiában három szakasza van: az eszme, a természet és a szellem. Ennek fényében tehát a természet, azaz a világ konkrét és megtapasztalható létezói mind a szellemi létezés elidegenedettjei, mely elidegenedés azonban az egész felé tart. Az emberi test-lélek kapcsolat is ebbe az egész felé tartó folyamatba ágyazódik be, amelynek végeredménye a teljes szellemi lét. Nem véletlen emiatt, hogy Hegel szavaiban néha mintha Spinoza is visszacsengene. ${ }^{7}$ Az emberi létezésnek tehát két féle dimenziója van tapasztalataink alapján, de az anyagi, érzéki, fizikai összetevôink csak úgy tekintendőek, mint az eszmeiból eredők és a szellemihez tartók.

\subsection{Materialista szubsztanciamonizmus}

A szubsztanciamonizmusok másik pólusa természetesen nem a szellemire akarja az anyagot, hanem éppen fordítva, a mentálisat akarja a fizikaira visszavezetni és azt azzal egyenlôvé tenni. Ezeknek az elméleteknek a hátterében megbújhat a dialektikus materializmus, a pozitivista vagy neopozitivista materializmus is, mely filozófiai irányzatok szerint az anyaggal képesek lehetünk megmagyarázni minden komplex jelenséget. Nem kell tehát különbséget tenni fizikai és esetleges metafizikai szintek között, hanem a fizikális világ egyre mélyebb ismeretén keresztül lesz felfedhetô számunkra az eddigiekben mint "szellemi", "anyagtalan", "anyagfeletti" jelenségek lényege. A világban bármi is történik, a történéseket minden esetben meg lehet magyarázni a pusztán anyagi eseményekból. ${ }^{8}$

Wirklichen Wirklichkeit gibt." WEISCHEDEL, W., Der Gott der Philosophen, Darmstadt 1983, 299.

${ }^{6}$ Vö. Ibid., 297.

${ }^{7}$ Hegel szerint Isten csak annyiban Isten, amennyiben tud önmagáról, s akinek önmagáról való tudása az emberben lévő öntudat. "Gott ist nur Gott, insofern er sich selber weiß; sein Sich-wissen ist ... ein Selbstbewußtsein im Menschen." Ibid., 286.

${ }^{8}$ Külön meg kell említenünk ebben a kontextusban a klasszikus logikai pozitivista doktrína elméletet, amely szerint a hagyományos metafizika egészét el kell vetni. Tudást ugyanis csak a tapasztalati tudományok nyújtanak, az ún. metafizikai vizsgálódások semmire sem vezetnek. Átfogó empirizmust képviselnek tehát ezen irányzat követői, akik szerint minden tudás csak kizárólag a tapasztalatból eredhet. Ezen felül azonban radikalizálják is metafizikaellenességüket, hiszen azt tartják, nemcsak hogy nem lehetséges tapasztalatokat gyüjteni bizonyos metafizikai tartalmakról - azaz tulajdonképpen megismerhetetlenek az efféle tartalmak, mint Isten létezése, a halhatatlan lélek kérdése -, hanem egyenesen értelmetlen ez a tudomány. Moritz Schlick szerint a metafizikai tudásnak nincs semmi eshetôsége. Otto Neurath szintén ezen az állásponton van; szerinte a metafizikával szemben a radikális fizikalizmusnak van létjogosultsága, amely még a tiltott metafizikai szavak jegyzékének (index verborum prohibitorum) elkészítését is megkívánná. Vö. AMBRUS G., Analitikus filozófia, Filozófia (szerk. Boros Gábor), Akadémiai Kiadó 2007, 1065-1145, 1094. 
A logikai pozitivista Moritz Schlick az emberi test-lélek kérdésben azt vallja, hogy két-nyelven történik meg a mentális jelenségek leírása. Egyrészt van egy introspekcióra támaszkodó pszichológiai nyelv, másrészt vannak a közvetett megfigyelésekre támaszkodó fizikai kifejezések, amelyeket szintén használunk. Azonban ennek a kétféle nyelvnek a használata egyáltalán nem azt jelenti, hogy azok két különbözố szubsztancialitásra vagy két különbözố szubsztanciabeli eseményre vonatkoznának. Ámbár használjuk az introspekciós pszichológiai nyelvezetet, ez a nyelvezet annak a metafizikának a következménye, amelyet teljes egészében el kell vetni.

A materialista hátterű elméletek között szerepel a behaviorizmus elmélete. Ez a koncepció abból indul ki, hogy az ember önmagát, bensôjét megfigyelheti és introspekción keresztül megállapításait szavakba is öntheti. Ezeket a megállapításokat azonban kívülállóként nem tudjuk ellenőrizni, hiszen én csak a saját magam bensôjébe tekinthetek, de képtelen vagyok belelátni a másik ember lelki és mentális állapotaiba. Ha a mentális belsô életet nem is tudom közvetlenül megfigyelni a másik ember esetében, hiszen csak a saját magunk esetében élhetünk az introspekció lehetőségével, azért sok mindent elárulhat nekünk az, hogy milyen külsô megnyilvánulásai vannak a másik embernek. Így a másik emberi személyrôl, általam vélt és gyanított belsó élményeirôl mégis csak tudok kijelentéseket tenni akkor, amikor a külsố viselkedését figyelem. Burrhus Skinnert, az amerikai pszichológust tekintjük a pszichológiai behaviorizmus egyik legfontosabb képviselójének, akinek elméletét több filozófus is analitikus változatban vezeti tovább. A behaviorizmus analitikus változata szerint nincs semmiféle lelki szubsztancia az emberben. Amikor mi a másik ember mentális élményeit próbáljuk meg szavakon keresztül megjelölni, akkor nem történik semmi, csak annyi, hogy bizonyos viselkedési, magatartási módokat és diszpozíciókat jelölünk meg. Tehát ebben az esetben sem találunk anyag- és fizikafelettit, hanem csak az emberi testnek fejezzük ki a különbözó diszpozícióit. Ilyen analógia alapján mondják a materialisták, hogy a lelki tulajdonságok tulajdonképpen csak a biológiai organizmusok viselkedései és különböző képességei. Minden mentális esemény a biológiai organizmus egészének egy-egy viselkedési diszpozíciója. Amit tehát lelki jelenségnek szokásos nevezni, az valójában nem más, mint olyan képességek összessége, amelyek meghatározzák, hogy bizonyos fizikai és társadalmi környezetben hogyan viselkedik valaki. Hogyan állapítható meg tehát, hogy valakinek fáj a feje? Úgy, hogy megfigyeljük, hogyan is viselkedik, amikor bizonyos hatások érik. Vagy esetleg látjuk azt, hogy megégeti valaki magát - ilyenkor eltorzul az arca, talán kiabál, vagy fél lábon fog ugrálni. ${ }^{9}$ A behaviorizmus analitikus változatának egyik képviselője Gilbert Ryle, aki a hétköznapinyelv-filozófiai áramlathoz tartozva vallotta a behaviorista tételeket az 1950-es évekig. Kiindulópontja az volt, hogy a beszélt nyelvben kategóriahibákat vét az ember, emiatt beszél test és lélek különbségéről. ${ }^{10}$ Ha ezek a hibák tisztázódnak, akkor megszûnik ez a fajta

\footnotetext{
${ }^{9}$ Vö. HUORANSZKI F., Modern metafizika, Budapest 2001, 213-217.

${ }^{10}$ A filozófia legfontosabb feladatának azt tartja Ryle, hogy az kiszúrje azokat a hétköznapi kifejezéseket, mondatokat, amelyek félrevezetőek. Sok esetben ugyanis a helytelen hétköznapi ki-
} 
természetünkre vonatkozó kettősség, s helyette mindent a viselkedési diszpozíciók kutatásán keresztül lehet megmagyarázni. A logikai behavioristák közé tartoznak még Paul Ziff, Norman Malcolm és B. A. Farrell is. ${ }^{11}$

A szubsztanciamonizmusok talán legjellemzőbb elmélete továbbá a materialista azonosságelmélet. Az azonosságelmélet szerint a mentális állapotok lényegüket tekintve mindig anyagi tulajdonságúak, mindig azonosíthatóak egy-egy anyagi állapottal. Tegyük fel, hogy valaki inni szeretne egy kávét, kívánja azt az íze és az élénkítô hatása miatt. Ennek azt a képletet adhatnánk, hogy a kávéivás vágyának mentális állapota mindig az ún. K mentális állapot lesz. Hosszabb kutakodás után az agyunkban arra döbbennénk rá, hogy a mentális $\mathrm{K}$ állapot, az minden esetben megegyezik az agyunk G állapotával. Lehet, hogy minden ember kávézási vágya lényegében csak abban merül ki, hogy az agyuk egy bizonyos régiójában bizonyos típusú idegsejtek égnek. Akik e teóriával szimpatizálnak, azok szerint előbb utóbb az idegsebészet minden mentális állapotra megtalálja majd a háttérben meghúzódó agyi fizikai folyamatokat. Ahogyan a víz azonos a H2o-val, úgy vágyaink, érzelmeink, élményeink egyenlőek az agyban található megfelelő fizikai folyamatokkal. Ennek az elméletnek egyik kedvenc példája az, hogy amikor egy élénk, erôs színú tárgyat szemlélünk hosszabb ideig, akkor a szemünket hirtelen becsukva, még pillanatok erejéig látunk egy az élénk színnel megegyezô utóképet - a becsukott szem ellenére még észlelünk egy azonos színú foltot. Hiába szünt meg a külsô stimulus, még az inger elmúlta után is egy bizonyos fizikai állapotban megmarad az idegrendszerünk. Ez a megfigyelés is mintha azt sugallná, hogy a lelki állapotaink, a mentális állapotaink azonosak lennének az idegrendszerünk meghatározott állapotaival. Az azonosságelmélet azt állítja tehát, hogy egy lelkiállapot mindig azonosítható egy idegrendszeri állapottal. Amikor pl. fájdalomról beszélünk, akkor ez teljes mértékben magyarázható mondjuk a C-típusú neuronok kisülésével. Ez az ingerület eljut az agyba, onnan tovább jutnak ingerületek az izmok felé, s ez okozza végül többek között a fájdalmat érző emberen megfigyelhető viselkedési módot is.

fejezések miatt jutnak a filozófusok helytelen metafizikai következtetésekre. Gilbert Ryle fố múve A szellem fogalma, mely az elme descartes-i felfogását veszi célba. A karteziánus koncepció szerint az elme egy privát belsố tér, olyan mint egy színház, melynek színpadján a mentális folyamatok zajlanak le. Ennek következtében a mentális folyamatokat mind okságinak tekintjük, amikor egy idea okoz, okozhat egy másik ideát. Az elménk továbbá oksági viszonyban van a testünkkel, viselkedésünket pedig a szubjektív szándékaink, céljaink és pszichológiai állapotaink határozzák meg. Ryle ezt az elképzelést a lélek szerkezetéról „paramechanikai hipotézisként” jellemezte, a test és lélek kapcsolatát pedig a ,gépezetben lakozó kísértet dogmájaként”, amely szerint a lélek valahol a mechanikus gépezetként felfogott testben/agyban kísért. A karteziánus megközelítés Ryle szerint kategóriahibán alapul, azaz különböző fajta létezôket egy típusú létezôkhöz akar sorolni a descartes-i filozófia. Ezzel szemben azt kell mondanunk, hogy az elme egyáltalán nem tárgy (szubsztancia) és egyáltalán nem tekinthetô okságinak az elme és viselkedés közötti kapcsolat. Az 1950-es évektől azonban Ryle feladja a behaviorista elméletet, hiszen pl. egy fejben eldúdolt dallam vagy egy csendben elvégzett számolás semmiféle külső viselkedéssel nem jár.

${ }^{11}$ Vö. ZIFF, P., About behaviorism, in: The philosophy of mind, V. C. Chappell (ed), New York 1957-58., MALCOLM, N., Dreaming, London 1959., FARRELL, B. A., Experiences, in: The philosophy of mind, V. C. Chappell (ed), New York 1957-58. 
A materialista monizmusok hátterében érvként a következő analógiák is meghúzódhatnak: Egy óra múködését a belső szerkezete magyarázza meg, ezért ha meg akarjuk érteni, akkor elemeire kell bontanunk, és így vizsgálhatjuk meg, hogy milyen részekból és e részek milyen összefüggéséból épül fel. Mielőtt azonban ennek a vizsgálatnak neki állnák, tisztáznunk kell, hogy egy tárgyat miért is azonosítunk óraként. Ez az azonosítás nem az alkotórészek alapján történik meg, hanem igazából a tárgy funkciója alapján - hiszen ezen a funkción keresztül vesszük észre a percek és órák elmúlását. Lefordítva ez a test-lélek problémára azt jelenti, hogy az embernek nincs lelke, hanem amikor lelki jelenségeket vélünk benne és rajta felfedezni, az pusztán csak az emberi test anyagi összetevőinek bizonyos funkciója és semmi más. Hasonló módon szoktuk mondani, hogy a „papír gyúlékony”, csakhogy közben azt tudjuk, hiába is keresnénk mikroszkóppal a papírlap egészén a gyúlékonyság tulajdonságát, azt nem találnánk meg. Ez a tulajdonság ugyanis egy olyan sajátos diszpozíciós tulajdonság. amelyet a papír csak bizonyos körülmények között mutat - amikor pl. nagyon magas a hómérséklet, amikor egyszerre van jelen az égéshez szükséges oxigén is, s amikor a papírlapunk lángra lobban. A test és lélek esetében ez szintén arra utal, hogy az emberi „lelki” jelenségek mind anyagiak, illetve az anyagiság törvényszerúségeiból következő az anyagnak a meghatározott körülményekre determinált módon történő válaszadása. Viszont ahogyan nem létezik a megfelelő feltételek hiányában a papír gyúlékonysága, úgy nem létezik önmagában az emberi lélek sem. Az azonosságelméletnek a képviselói az 1950-es évektől jelennek meg, az 1990-es évekból ismertebbek közülük Macdonald, Hill és Papineau. $^{12}$

\section{Válaszok a szubsztanciadualizmus területérôl}

A szubsztanciadualizmus szerint - szemben a fent említett elméletekkel - az emberi elme alapvetően különbözik az emberi testtől, elme és test két különbözó dolognak tekinthetőek. Az elme az emberben a mentális szubsztancia, amelynek egyetlen egy fizikai tulajdonsága sincs, így elkülönül minden fizikai dologtól, továbbá képes önmagában függetlenül minden fizikai tárgytól elkülönülten létezni. Ha valakirôl

\footnotetext{
${ }^{12}$ Vö. MACDONALD, C., Mind-body identity theories, London 1989., HILL, C., Sensations: a defense of type materialism, Cambridge 1991., PAPINEAU, D., Philosophical naturalism, Oxford 1996. E nevek megemlítésekor érdemes felhívni a figyelmet Hilary Putnamra is, aki az azonosságelmélet legismertebb ellenlábasa. Véleménye szerint a mentális állapotok azért nem lehetnek teljesen azonosak neurofiziológiai állapotokkal, mert a mentális állapotok más-más módon valósulnak meg a különbözó élólényekben. Tudjuk, hogy a különbözô élólények idegrendszere között nagyok a különbségek, és így amikor azonos pszichológiai predikátumokat használunk különbözô élólényekre, mint pl. fájdalom, akkor implauzibilis azt állítani, hogy ezekben az esetekben azonosak a neurofiziológiai állapotok. Putnam szerint: „Amennyiben találunk egyetlen olyan pszichológiai predikátumot, amelyet egyaránt alkalmazhatunk emlősállatra, és egy polipra (például azt, hogy 'fájdalma van'), ám melyeknek a két esetben különböznek a fizikai-kémiai korrelátumai, akkor az azonosságelmélet összeomlik. Roppant valószínúnek tûnik számomra, hogy találhatunk ilyet." TŐZSÉR J., - ULLMANN T., A ,lélek” fogalma a 20. századi filozófiában, Mentofaktúra folyóirat - filozófia és coaching 1 (2009), 8., http://www.mentofaktura.hu/1szam/tozser1.pdf
} 
azt mondjuk, hogy egy gondolat jár a fejében, van benn egy bizonyos érzelem vagy észlelet, akkor ezek a mentális állapotok a mentális szubsztancia állapotainak tekintendők.

Akik a szubsztanciadualizmust nem fogadják el - mint ahogyan láttuk fentebb a monista álláspontokat -, azok arra hivatkoznak, hogy test és lélek alapvető különbsége esetén nagy nehézségekbe ütközik a kettejük közötti oksági viszony, nehézkessé válik a mentális okozás magyarázata. Sok filozófus ugyanis elismeri és vallja a fizikai világ oksági zártságát, mely tézis azt mondja ki, hogy a fizikai események okai és okozatai nem vezetnek ki a fizikai események köréból. Úgy is mondhatjuk: „Minden egyes e fizikai eseményt (beleértve az emberi cselekedeteteket is) az azt megelőzó e' fizikai esemény okozza olyan módon, hogy e' - a megfelelő fizikai törvényekkel összhangban - önmagában elégséges e elôidézéséhez. Mármost - és ez a fố probléma! - ha elfogadjuk a fizikai világ oksági zártságának elvét, akkor úgy túnik, a szubsztanciadualista tagadni kényszerül a mentális okozást." 13 A dualista elméleteknek ennek alapján vélhetôen az lesz a feladatuk, hogy a két különböző szubsztancia kapcsolatára mégiscsak adjanak valamilyen magyarázatot. Ezeket tekintjük át a következô oldalakon.

\subsection{Descartes és követői}

Az újkor egyik legmeghatározóbb alakja Rene Descartes, aki kifejezetten a szubsztanciadualizmus elméletét képviseli az emberi test és lélek kapcsolatban. Descartes szerint teljesen különböző entitás a kettő. Kiindulópontként azzal érvel, hogy világosan és tisztán el tudja képzelni a lélek test nélkül való létezését, és így szerinte ennek alapján lehetséges, hogy a lélek a test nélkül egzisztáljon. Amennyiben ugyanis ezek elkülönített mivoltukban tisztán elgondolhatóak, akkor valószínúleg úgy is léteznek.

Hogyan zajlik azonban ezt megelőzően a test és lélek között „kommunikáció”, azaz milyen kapcsolat van a kettő között? Descartes szerint, ha pl. túszúrás éri az ujjam, akkor a tûszúrás helyérôl jelzések indulnak meg az agyunk felé, és ott a tobozmirigyben ezek a testi események átalakulnak anyagtalan információvá, amelyet így az emberi elme felfog és megért, azaz a lélek értesül a testi eseményekrôl.

Descartes úgy véli, hogy ami anyagi, annak van kiterjedése, és időben létezik - ez lesz minden res extensa (kiterjedt dolog) tulajdonsága. Ezzel szemben a lelki szubsztanciáknak nincsen térbeli kiterjedése. Ahol nincs kiterjedés és a változásokat nem lehet geometriai tulajdonságokkal szemléltetni, ott lelki történésekrôl van szó, melyek a térbeliség és geometriai adottságok hiányában semmiféle módon nem hozhatóak kapcsolatba a fizikai törvényekkel. Másrészt a lelki szubsztanciák második nagyon fontos tulajdonsága a gondolkodás, amely alatt nem pusztán a logikus, a következtető gondolkodást kell értenünk, hanem mindent de mindent, ami az emberi elmében tudott, tudatosként megjelenik, így az érzelmek, érzések, kételkedések, hitek és vágyakozások is. Ebben az esetben tágabb értelemben szere-

\footnotetext{
${ }^{13}$ Vö. TÕZSÉR J., Metafizika, Budapest 2009, 208.
} 
pel tehát a gondolkodás: nem egy olyan lelki folyamatot ért alatta Descartes, ami kifejezetten valamilyen probléma megoldására irányul, hanem annyit jelent, hogy „,valami jár a fejünkben”. Descartes innen bontakoztatja ki a „felfoghatósági érv”-et, ami arra utal, hogy fel tudom azt fogni, hogy ne létezzenek tárgyak körülöttem, s mivel a testem is fizikai tárgy, így azt is el tudom képzelni, hogy nincs testem sem. Mint, amikor pl. minden erómmel arra törekszem, hogy az érzékszerveimet kikapcsoljam, és figyelmen kívül hagyjam az általuk közölt aktuális üzeneteket ilyenkor tényleg úgy túnik, hogy test nélkül is létezhetek. Azt viszont már nem tudjuk felfogni, hogy ne legyen valaki, aki figyel, pontosabban, hogy ne legyen valaki, aki azt gondolja, hogy figyel. S mi más lenne ez, mint a test nélküli lélek? Ennek alapján születik meg Descartes radikális szubsztancia dualizmusa: Mivel a lelket el tudom képzelni a testem nélkül, így azok biztosan külön is, egymás nélkül is tudnak létezni. ${ }^{14}$ Ha minden fizikait le is tagadok vagy kizárok, a gondolkodás tényét magát biztosan nem tudom tagadni - így marad az egyszerú képlet: ahol gondolkodás van, ott van a lélek!

Akik Rene Descartes koncepcióját vitatják, azok leginkább amiatt teszik ezt, mert problémát vélnek felfedezni a res extensa és a res cogitans kapcsolatában, a kettô közötti közvetítésben. Szerintük kérdéses a tobozmirigynek és egyáltalán bármilyen más elképzelt agyi helynek az a fajta szerepe, ami egy ilyen közvetítô szerepet töltene be testi és testetlen között. Hogy hogyan történik a matéria és descartes-i elme közötti interakció, az meggyôzốn meg nem válaszolható. Ugyanakkor olyannyira kiemeli a lélek önállóságát, hogy közben elveszti az testbenlélekben létezố ember alapvetô egységét. ${ }^{15}$

\footnotetext{
${ }^{14}$ „Fölteszem tehát, hogy mindaz, amit látok, hamis. Nem hiszem el, hogy valaha bármi is létezett volna azok közül, amiket a csalóka emlékezet megjelenít. Nincs semmiféle érzékszervem. A test, az alak, a kiterjedés, a hely - mindez csupán kiméra. De hát akkor mi marad igaz? Talán csak az az egy, hogy semmi sem bizonyos. Na de honnan tudom, hogy nincs valami, ami különbözik mindattól, amit épp az imént soroltam fel, s amivel kapcsolatban a legcsekélyebb kétely sem merülhet fel? Nincs-e valaminő Isten, vagy nevezzük bárminek azt a lényt, aki akár ezeket az iménti gondolatoka is belénk ülteti? De vajon mi értelme volna föltenni egy effajta lényt, ha egyszer lehetnék akár én magam is e gondolatok szerzóje? Nem vagyok-e tehát legalább én valami? De hiszen már tagadtam, hogy volna bármiféle érzékszervem, bármiféle testem! Itt azonban megakadok, mert mi következik ebből? Vajon annyira hozzá vagyok-e kötve a testhez, az érzékszervekhez, hogy nélkülük nem is létezhetem? De hiszen már meggyôztem magam arról, hogy nincs a világon semmi sem: nincs ég, nincs föld, nincsenek elmék, nincsenek testek. Nem gyôztem-e meg magam ezáltal már arról is, hogy én magam sem létezem? Semmiképp! Bizonyos, hogy én voltam, ha egyszer meggyőztem magamat valamirôl. Igen ám, de ha van valamiféle rendkívül nagyhatalmú, rendkívül agyafúrt csaló, aki állandóan megtévesztve engem, méghozzá szándékosan? Nos, hát akkor aligha kétséges, hogy én is vagyok, ha egyszer engem téveszt meg! Tévesszen csak meg, amennyire tud, azt mégsem lesz képes elérni sohasem, hogy ameddig azt gondolom, vagyok valami, semmi se legyek. Olyannyira, hogy - mindent kellóen megfontolván végül is le kell szögezni: az "én vagyok, én létezem" kijelentés - valahányszor kimondom vagy elmémmel megragadom - szükségszerủen igaz." DESCARTES, R., Elmélkedések az elsố filozófiáról, Atlantisz 1994, 33-34.

${ }^{15}$ Itt jegyezzük meg röviden, hogy Descartes úgy tûnik akaratán kívül, de egyértelmúen szakít a középkori keresztény hagyomány emberképével, hiszen a szent tamási Arisztotelészre épülő elméletet egy platonista ízú elméletre cseréli le, amikor a teljes test-lélek dualizmust fogalmazza meg. Az emberi res cogitans és res extensa tana ugyanis annyira szélsôséges, hogy lélek és test
} 
Ezeken a descartes-i hibákon próbálnak meg szépíteni az okkazionalisták, a holland Geulincx és a francia Melabranche, akik szerint a test és lélek kölcsönhatásában is az isteni okságot kell felfedeznünk. Nem test és lélek hatnak egymásra (mondjuk a tobozmirigy esetleges közvetítő közegében), hanem Isten okozza a testben és a lélekben a különböző hatásokat. Ezeknek az isteni hatásoknak köszönhető, hogy a test és lélek együttmúködése számunkra egymásrahangolt módon jelenik meg. Az okkazionalizmusban Isten causa universalis-szá válik, aki minden testi és lelki közötti eseménynek a kizárólagos magyarázatává lesz. Geulincx szerint nem tudjuk megválaszolni azt, hogy hogyan válik egy akarati elhatározás, mint tudattartalom az agyunkon, az idegeken keresztül izmok megmozdulásává. Azt sem tudjuk továbbá megérteni, hogy a testünk egy érzékszervét elérô anyagi stimulus hogyan válhat tudatos érzéki észleléssé. Az emberi létezô szerinte csakis a saját szellemében képes önmagára hatni, csakis a szellemi szférában képes cselekedni és változásokat előidézni. A test már nem tartozik énünkhöz, hanem arra csak Isten képes hatni - amikor az akarati aktusunk erre alkalmat szolgáltat. Ha pl. egy követ akarok a kezemmel megmozdítani, bár az erre irányuló akarati aktus természetesen énemból tör elô, de a kô tényleges megmozdításához a szükséges erô már kívülrôl érkezik, mégpedig az istenségtool. Ehhez hasonlóan, amikor egy érzéki észlelet elérkezik a testünkhöz, amit a körülöttünk lévố világ ad egy bizonyos kép alakjában, akkor ennek az énünkbe történô beszivárgása, a szellemünkben való megjelenése szintén az istenségnek köszönhetô. 16 Ezzel párhuzamosan vélekedik Melabranche is. A francia gondolkodó elképzelése szerint, amikor valamit tenni akarok, akkor ez az akarás egy anyagtalan esemény a szellememben. Ez az eset a következó lépésben Isten által egy bizonyos fajta regisztráción megy keresztül, és ezután kerül majd megfelelő mozgásba az általam akart a test.

Hasonló szubsztancia dualizmust képvisel Karl Popper a XX. sz.-ban, aki azonban a descartes-i jellegú válaszhiányokat más módon próbálja meg orvosolni. Híres háromvilág-elmélete jelentheti a testi és lelki közti interakció lehetôségét. Szerinte van egy materiális világ, mellette van a mentális világ, s harmadsorban van egy olyan világ is, amelyben az emberi szellem produktumai vannak, melyek függetlenül léteznek minden egyes individuális tudattól, s amelyek ugyanakkor az elsô világban bekövetkezố változásoknak az igazi okai. E harmadik világba soroljuk be a tudományos elméleteket, felvetéseket, az emberiség által ismert problémákat és érveket, minden múalkotást és minden társadalmi intézményt. Ennek a harmadik világnak a részesei tehát mind emberi alkotások, melyek ideákként léteznek, amelyeknek története van, ugyanakkor képesek visszahatni az emberi történelemre,

esetében már szinte semmiféle kölcsönhatásról nem beszélhetünk. E két szubsztancia természete nem engedi meg, hogy lényegi egymásra hatás történjék meg közöttük; a léleknek többé már nem kell a test, hogy rajta keresztül megnyilvánulhasson; a testnek meg nem kell a lélek, hogy élhessen, hiszen automata lett belóle. Itt találjuk meg az újkori test-lélek probléma gyökerét. Descartes hiába igyekszik a sorbonne-i teológusok előtt védelmezni és érvek sokaságával alátámasztani koncepcióját, elszakad teljesen a keresztény felfogástól. Mivel a testet és lelket teljesen különböző valóságoknak tekinti, már nem sikerül neki e kettősségben az ember lényegi egységét megtalálnia.

${ }^{16}$ HIRSCHBERGER, J., Geschichte der Philosophie, Band II, Freiburg-Basel-Wien 1991, 126. 
az emberek által pedig a fizikai világ változásainak válhatnak okukká. ${ }^{17}$ Hogy a harmadik világ elemei azonban hathassanak az elsô világra, ahhoz az kell, hogy a második világ részesei (tehát az egyes emberi tudatok) azokat recipiálják és megvalósulásukban segítsék, hiszen önmaguktól képtelenek erre.

\subsection{Leibniz pszichofizikai parallelizmusa}

Descartes elméletét füzi még Leibniz is tovább, aki a „harmonia praestabilitata” fogalmán keresztül mutatja fel, hogy test és lélek úgy érthetőek meg, hogy azokat monászoknak tekintjük. Minden monász belső aktivitásán keresztül bontakozik ki, s a világot alkotó végtelen számú monászi kibontakozások az Isten által szabályozott harmónikus, minden létezô egymásrahangoltságát biztosító együttes folyamatba illeszkednek bele. Az eszes lélek, azaz a szellem Leibniz szerint többletet jelent a monaszokhoz mérten - ugyanis a szellem nem csak tükrözi a teremtmények összességét, hanem egyben képmása az istenségnek is, ami által ő maga is létre tud hozni Isten múveihez hasonló kisebb múveket. ${ }^{18}$ Amíg az ember teste nagyszámú alacsonyabb rangú monászok egysége, addig az emberi lélek magasabb rendú monászok egysége: ebból a kétféle monászcsoportosulásból áll össze a konkrét emberi lény. Másrészt azt is hangsúlyozza Leibniz, hogy az emberi szellem az örök igazságok révén közösségre tud lépni az Istennel, és így lesz Isten országának tagja. Ezeket az örök igazságokat nem nyitott könyv módjára lehet olvasni, hanem a fegyelmezett „,figyelem segítségével” fedezhetjük fel magunkban, „és ehhez az érzékek szolgáltatják az alkalmat." 19 A leibniz-i metafizikában a testet és lelket alkotó monászok különbsége egyértelmúen a szubsztanciális kettősség okává lesz. E kettôség eseményei azonban teljesen egy időben zajlanak, az embert érintő szellemi és anyagi események egymással párhuzamosan egymásra szinkronizálva történnek, ezért is nevezik ezt az elméletet pszichofizikai parallelizmusnak. E teória fényében megszúnnek az interakciós problémafelvetések is, nem kell semmiféle közvetítő helyet keresgélni az emberi agyban. A mentális és a testi események úgy zajlanak egymással párhuzamosan, mint ahogyan a szinkronizált órákban teljesen ugyanazon pillanatokban mozdulnak meg a kis és nagy mutatók.

Leibniznek az emberi test-lélek tematikát érintő gondolataiból fontos még megemlíteni a malom-hasonlatot, amin keresztül az ember szellemi tevékenységét igyekezett egyértelmú módon elkülöníteni az anyagi, az emberi agyban lejátszódó fizikai és kémiai folyamatoktól. Az ember percepciói nem magyarázhatóak pusztán a mechanikai okokkal, ez az, amit igazolnia kell és igazolni szeretne a leibniz-i filozófia. A malom-hasonlat szerint, ha elképzelünk egy gépet, melynek szerkezete lehetôvé teszi, hogy gondolkodjék, érezzen és percepciói legyenek, és képzeletben megnöveljük akkorára, hogy - arányait változatlanul meghagyva - beléphessünk ebbe a gépbe, akkor rájövünk, hogy csak egymást hajtó alkatrészeket látunk benne, de

\footnotetext{
${ }^{17}$ Vö. AMBRUS, Analitikus filozófia, 1119.

${ }^{18}$ Vö. LEIBNIZ, G. W., A természet és a kegyelem ésszerúen megalapozott elvei, Válogatott filozófiai írások, Budapest 1986, 291-327.

${ }^{19}$ LEIBNIZ, G. W., Újabb vizsgálódások az emberi értelemról, Budapest 1930. I. 1.
} 
azt meg nem találjuk, amivel éppen a percepciót lehetne magyarázni. Ez jelenti tehát a szellemi szubsztancia belső tevékenységét, amit nem lehet fizikai múködésre redukálni. Ma már nagyon részletesen ismerjük az emberi agy múködését, annak funkcionális felépítettségét, és a benne zajló fizikai és kémiai folyamatokat. Ennek ellenére bármit is tenne egy agysebész az aggyal, a benne lévó gondolatokat nem láthatja soha sem, és a beteg páciens érzelmeit sem tudja átérezni. Bármely részletességgel is térképezné fel egy agykutató valakinek az agyát egy computertomográffal, abban gondolatokat, vágyakat és érzelmeket úgysem fog találni. ${ }^{20} \mathrm{~A}$ leibnizi filozófia szerint tehát nem azonosíthatjuk a tudatos állapotokat egy biofizikai vagy fiziko-kémiai állapot megadásával.

\subsection{Epifenomenalizmus}

Az epifenomenalizmus elmélete szintén a szubsztanciadualizmus egyik válfaja, amely szerint az anyag hatni képes az anyagtalan szellemi lélekre, de ez fordítva viszont nem történhet meg. Thomas Henry Huxley a legfóbb képviselóje ennek a felfogásnak, akinek a metafizikai álláspontját egy egyirányú utca képével is modellezhetnénk, hiszen kauzális okozás szerinte csak az egyik irányban valósulhat meg. E metafizikai álláspont szerint tehát a mentális eseményeknek nincs önálló kauzális hatásuk, képtelenek kihatni az anyagi, fizikai vagy testi eseményekre. Huxley úgy gondolja, hogy minden mentális folyamat egyszerúen csak kísérôje a fizikai folyamatoknak. Egy megfázás okozhatja pl. az ember pirossá lett orrát, de egy piros orr soha sem okozhat megfázást - ez a folyamat ugyanis visszafelé nem múködik. Huxley a következóképpen fogalmaz: „Az elmét a testi mechanizmusok munkájának (mellék)termékeként kell tekintenünk, amely körülbelül annyi képességgel rendelkezik arra nézvést, hogy e munkát befolyásolja, mint amennyivel a gốzmozdony múködését kísérô vonatfütty rendelkezik arra nézvést, hogy befolyásolja a vonat haladását." 21

\subsection{A szuperveniencia és az emergencia elmélete}

A szuperveniencia elmélete szerint a mentális állapotok szuperveniálnak a fizikai állapotok felett, azaz a mentális események ráépülnek a fizikai eseményekre, de nem tehetóek egyenlővé velük. Az elmélet hangsúlyozza, hogy vannak lelki tulajdonságok, azok valóságosan léteznek, és semmiképpen sem szabad azokat fizikai tulajdonságokra redukálni. A lelki és fizikai között egy érdekes függôségi viszony áll fenn, mely szerint a mentális állapotban nem következhet be változás anélkül, hogy közben ne változna a fizikai állapot, ugyanakkor egy-egy azonos lelkiállapotnak lehetnek más-más fizikai alapjai. A szuperveniencia elmélet szerint egy A tulajdonság akkor szuperveniál B tulajdonságon, ha nem lehetséges, hogy két dolog anélkül különbözzön A tulajdonsága tekintetében, hogy B tulajdonsága tekintetében is különbözne. Ez azt jelenti, ha rögzítem pl. az egyik mentális tulajdonságot,

\footnotetext{
${ }^{20}$ HUORANSZKI, Metafizika, 205.

${ }^{21}$ TŐZSÉR, Metafizika, 212.
} 
akkor ezzel még nem határoztam meg a neurofiziológiai tulajdonságot, tehát nem redukáltuk a mentális tulajdonságot egy bizonyos neurofiziológiai tulajdonságra, és ezzel még összhangban vagyok a többszörös megvalósíthatóság eszméjével is ; ha azonban rögzítem a neurofiziológiai tulajdonságot, akkor ezzel már meghatároztam a mentális tulajdonságot is egyben. Másképp magyarázva, ha „két mentális tulajdonság különbözik egymástól, akkor a hozzájuk tartozó neurofiziológiai tulajdonságok is különböznek egymástól, de ez fordítva nem áll: lehetséges, hogy ugyanannak a mentális tulajdonságnak különbözô típusú neurofiziológiai tulajdonságok feleljenek meg." 22

A szuperveniencia egy olyan sajátos függóségi reláció, melynek segítségével értelmezni tudjuk például azt is, hogy miként lehetséges az, hogy a fájdalomcsillapító hatására megváltozik fájdalomérzetünk, de nem létezik olyan gyógyszer, amellyel meg tudnánk változtatni gondolataink tartalmát. Amikor egy bizonyos típusú fájdalmat érzünk, mindnyájan ugyanabban a típusú fizikai állapotban vagyunk. Ezért a fájdalomcsillapító ugyanúgy fog hatni ránk. Viszont a gondolatok tartalmának azonossága nem feltételezi, hogy pontosan ugyanabban a fizikai állapotban legyünk. Ezért nem lehet olyan drogot elóállítani, amely egységesen ugyanazokat a gondolatitartalom változásokat fogja okozni mindnyájunkban. Ez magyarázza, hogy a hallucinogének miért keltenek hasonló érzéseket anélkül, hogy pontosan ugyanazokat a gondolatokat, látomásokat keltenék mindenkiben. Ez azonban önmagában nem jelenti azt, hogy gondolataink tartalma egyáltalán ne függne agyunk fizikai állapotától. Nem változhat meg pl. valamely meggyốốdésünk anélkül, hogy agyunkban ne történne valamilyen fizikai változás. ${ }^{23}$

Az emergencia olyan jelenségekre utal, amelyek egy rendszer makrofelszínén jelennek meg, de közben észrevehetetlenek a rendszer mikrofelszínének összetevőin. $\mathrm{Az}$ emberi öntudat ennek alapján emergens módon van jelen az emberi lényben, hiszen az emberi személyek rendelkeznek vele, de ezt az öntudatot soha sem tulajdoníthatjuk az emberi test egyes részeinek. Ez az elmélet egyrészt elképzelhetônek tartja, hogy minden valós a legapróbb anyagi részekből tevődik és áll össze. Másrészt azonban ragaszkodik ahhoz a megállapításhoz, mely szerint vannak anyagtalan tulajdonságok. Az, hogy „,valami valamilyen módon megélt/átélt lesz”, ez egy anyagtalan tulajdonság, amely egy rendszer (az emberi organizmus) makrofelszínén jelenik meg.

\section{Szemléletváltás a test és lélek kérdésben}

Amikor test és lélek természetéról értekeztek a különböző filozófiai irányzatok, akkor azt hosszú időn keresztül abból a szemszögboól tették meg, amit az élet és halál összefüggés szemszögének nevezhetnénk. Mind Platón, Arisztotelész és persze a kereszténység számára azt is fontos volt megmutatni, hogy vajon mi történik az

\footnotetext{
${ }^{22}$ Ibid., 222.

${ }^{23}$ Vö. HUORANSZKI, Metafizika, 208.
} 
emberi halál után. Egy élő test nem olyan, mint egy elhalálozott ember teste, még akkor sem, ha a kettő anyagiságát tekintve gyakorlatilag ugyanazokból az elemekból áll össze. Emiatt szükséges feltételezni egyfajta életerôt, azt a lelket, mely élettel hatja át az anyagot, és élő organizmust hív elő. A test és lélek kettôsség és egység vizsgálata tehát mindig a halál utáni történésekre is szeretett volna választ adni. A filozófiai érvelések nem csak akörül forogtak, hogy vajon hogyan jelenik meg az emberi élólény a test és lélek összetételében, hogyan válik az élő valósággá; hanem egyidejúleg akart a halál eseményre is reflektálni, amely eseményben az élô tulajdonság már megszúnik. Ebból a szemszögból tekintették a lelket a pszichésszellemi és ugyanakkor a fizikai-biológiai élet okának is egyszerre.

\subsection{Anyag-forma interpretáció és a pszichoszomatikus látás- mód}

A késóbbi filozófiai test-lélek koncepciókban azonban történik egy fontos szemléletváltás, mert benne a vizsgálatok elsődleges célpontja a pszichoszomatikus jelenségekre tevốdik át. Tudjuk, hogy a szellemi (lelki) események kihatnak a testire. Egy akarati elhatározás okozza pl. a karok és emberi lábak mozgását, vagy pedig a lelki izgatottság okozhatja az élénkebb véráramlást, és az elfojtott komplexusok pedig egyenesen fizikai megbetegedést is előidézhetnek. Ellentétes irányú mozgás tanúi vagyunk akkor, amikor a fizikai történés okozza a pszichében bekövetkező változást. Súlyos testi betegségek pl. negatív módon befolyásolják a lelket és levertté teszik az embert, vagy pedig ilyen jelenségnek számít az, amikor erôs gyógyszerek vagy drogok által teljesen elváltozik az ember tudatállapota. Ezekben az esetekben tehát fizikai beavatkozások és jelenségek vezetnek a mentális változásokhoz. Igaz hogy a pszichoszomatikus jelenségeknél mindig testrôl és lélekrôl beszélünk, csakhogy itt ezek a szavak jelentésüket tekintve némileg módosulnak. A pszichoszomatikust elemző pszichológia számára a „lélek” már nem az életelvet, nem a test formáját jelenti, hanem pszichikai események és pszichikai történések foglalatává válik! A „test” pedig innentól fogva nemcsak a pusztán testit jelenti, - ami önmagában csak élettelen szubsztrátum, és ami a lelket igényli az élôvé váláshoz - hanem úgy jelenik meg, mint élố emberi organizmus, bár fizikális valóságában különbözik a pszichés élettől. Az anyag-forma (arisztotelészi-tomista) értelmezés tehát ezen a ponton megszúnik! Az ember úgy jelenik meg, mint akit két elkülönülố megnyilatkozási szinttel jellemezhetünk: benne a fizikális és a mentális szintek hatnak egymásra. $\mathrm{Az}$ anyag-forma interpretáció helyét átveszi a pszichoszomatikus látásmód. ${ }^{24}$

Végül meg kell említenünk azt is, hogy mai korunkban az elmefilozófia az a tudományág, amely tovább vezetve a pszichoszomatikus szemléletváltást arra próbál meg választ adni, hogy a különbözố szellemi és mentális állapotok milyen természetűek, milyen okokhoz vezethetjük azokat vissza és vajon milyen hatással bírnak. E kérdéseket a mentális és testi (biológiai) állapotok kapcsolatának fókuszában vizs-

\footnotetext{
${ }^{24}$ Vö. CORETH, E., Was ist der Mensch? Grundzüge einer philosophischen Anthropologie, Innsbruck-Wien-München 1980, 150-152.
} 
gálják a kutatók. Fơkérdésük az, hogy a mentális állapotok hogyan viszonyulnak a fizikai állapotokhoz, azaz a test biológiai funkcióihoz, az ember agyi szervéhez. Két különbözô szubsztanciának tekinthetőek vagy végül is egy és ugyanazon valóságot fedik? Emiatt teszik meg alapvető különbségnek a test és lélek összefüggésre adott válaszokban a szubsztanciadulaizmust és szubsztanciamonizmust, amit a fentebbiekben is igyekeztünk bemutatni.

\subsection{Az ember, mint egységes létező - a szellem, mint az emberi test lelke}

Test és lélek összefüggésének sok-sok filozófiai elmélete ide vagy oda, hétköznapjainkban úgy tekintünk magunkra, mint egységes létezôre. Emerich Coreth, az osztrák teológus és filozófus szerint éppen ezért eleve elhibázott az embert érintó kérdésünk, ha róla úgy kérdezünk, mint aki egyfajta kettôsségból vagy akár elemek többségéből áll össze. A bennünk tapasztalható sokszínûség és sokszerûség ellenére ugyanis az egység az, ami elsôsorban jellemez bennünket. Tudatunk szépen elboldogul azzal, hogy különbözô érzelmeinket, akarati aktusainkat, ösztöneinket, hangulatainkat, emellett testi állapotainkat, cselekedeteinket és szenvedéseinket is egységben tartsa, azokat össze- egybefogja, és az én-ünkre vonatkoztassa. Ennek alapján tehát mindig a konkrét emberról van tapasztalatunk, aki egész, aki egységes és nem pedig darabokra szétesett. ${ }^{25} \mathrm{Az}$ én az, aki az egészet, egészünket adja, aki bennünket egységes létezôvé tesz. Persze az egység az ember esetében nem egy homogén egység, hanem differenciált és heterogén. A testünk egyrészt úgy van előttünk, mint élő organizmus. Az emberi testet sohasem tekintjük pusztán olyan anyagi összetételnek, mint egy kô vagy egy asztal, a testünk mindig elkülönül a halott emberi tetemtől és az anorganikus dolgoktól. Van a differenciáltságunknak egy biológiai szintje, amelyben találkozunk a lélegzéssel, szívdobogással, véráramlással, emésztéssel és vegetatív idegrendszeri tevékenységekkel. Ettől elkülönülten azonban azt is észrevesszük, hogy a biológiai felett válnak valóssá érzelmeink, érzeteink, észleleteink. Ebben fontos szerepet játszanak az érzékszerveink, melyek által a szervezetünk válaszokat ad a külvilágnak az érzéki törekvéseinken és az ösztönös megnyilvánulásainkon keresztül. A szenzitivitást követő terület pedig harmadikként az emberi szellemi tevékenység. Az ember jelen van önmaga számára, érzetei, érzékelései felett mindig ott lebeg a tudatos én, aki szabad önrendelkezésével uralhatja és legyốzheti a közvetlenül adott ösztönöset.

Az általunk megtapasztalt bennünket érintô egység tehát hármas tagoltságú (biológiai, szenzitív és szellemi), csakhogy ez a három „életformánk” egymás nélkül a mi esetünkben elkülönülten nem létezhet. Az elképzelt pusztán biológiai emberi élólény nem lenne képes a biológiai létezésre, ha nem lenne közben szellemi tevékenysége - mint emberből átalakult állati létező nem lenne képes a túlélésre. Éppen így igaz az is, hogy elveszne a gondolkodási képességünk, ha az agyi szervünk károsodik, ha agysejtjeink kóros módon elváltoznak. Amikor tehát elkülönítjük a

\footnotetext{
${ }^{25} \mathrm{~V}$ ö. Ibid.
} 
vitális, érzéki és szellemi képességeinket, akkor ezt nem tehetjük meg annak árán, hogy azokat egymástól teljesen függetlennek tekinthetnénk megnyilvánulásaikban. Nem rendelkezünk pusztán szellemi cselekményekkel vagy pusztán érzékeléssel vagy pusztán vegetativitással. Ezek a minőségileg elkülönülő szférák egymást kölcsönösen feltételezik. ${ }^{26}$

Ha tehát magunkat egységes létezőnek tekintjük, ha énünk integritását tapasztaljuk, akkor mondhatjuk, hogy a lélek bennünk a formaelv. Ez nem egy dolog, amely a testben több testi funkció mellett, mint egy másik rész állna fenn. Tisztán metafizikai elv, amely nem dologszerúen áll fenn önmagában, hanem csak formaadói, lényeget meghatározó funkciójában tekintve oka a teljességében tekintett emberi élet egységének és eredetének. A lélek az, ami az embert azzá teszi, ami, mely az ember egységét és teljességét konstituálja. ${ }^{27}$ Amikor magunk elôtt látjuk az emberi testet, akkor azt úgy is látjuk, mint bizonyos anyagokból összeállót, konkrét kémiai elemekből felépülőt. Ezek a kémiai anyagok a táplálkozáson keresztül beépülnek a testbe, és részét alkotják a testben végbemenô anyagi folyamatoknak. A beépülés minden esetben az emberi szubsztanciális egységbe történik meg szigorúan meghatározott törvényszerúségek alapján. Ezeket a törvényszerúségeket és magát a szubsztanciális egységet is a léleknek köszönhetjük. A lélek tehát, mint formaelv „,vezényli” az újabb és újabb anyagok beépülést és feldolgozását az egységes emberi létezóbe, egységes emberi testi funkciókba. A lélek az, ami a testet érintô minden egyes történést az egységes, a teljes test-történésbe épít bele. Az emberi létezốt jellemzô élô struktúrának, a vitális, az érzéki, a szellemi élet kibon-

\footnotetext{
${ }^{26} \mathrm{Az}$ elkülönülő szférák természetesen a növényi, állati és kifejezetten emberi életminőségeket jelentik. Az élettelen testeket a növények azzal szárnyalják túl, hogy bennük az elkülönülő növényi részek az egész növény szolgálatában állnak. Egy növény életéhez szükséges a gyökerek, szár, levelek egymásra hangolt tevékenysége. E tevékenységek az egészre vannak rendelve, hogy a növény elkülönülhessen a környezettől, hogy önmagát szervezze és fenntartsa. Ezt követi az állati létezés, amelyben nemcsak az érzéki adatok lecsapódása és érzéki észleletek felvétele történik meg, hanem ezek megmaradhatnak az emlékezetben, ezekre születhet válasz az érzéki ösztönök közegében. Éppen ezért kell az állatokban egy úgynevezett érzéki centrumot feltételezni, mely központja a benyomások felvételének, raktározásának és az azokra adható ösztönös reakcióknak. Ezáltal tud az állat magasabb fokon egységet képezni és környezetétől még függetlenebb módon elkülönülni. Végül az emberi létezés szellemisége arra ural, hogy az emberben az érzéki centrumot is felülmúlja az én, hogy afelett rendelkezzen, és hogy önmagát így birtokba vehesse. Az ember tehát teljes mértékben jelen van önmaga számára, szellemi tevékenységén keresztül felismeri környezetét és abban minden jelenséget, de egyikkel sem azonosul. A növényi, állati és emberi létmódok sajátságait, alapvető különbségeit, radikális elkülönültségeit jól bemutatják és elemzik a XX. századi szerzók, mint Scheler, Gehlen és Plessner. Vö. SCHELER, M., Az ember helye a kozmoszban, Budapest 1995., GEHLEN, A., Az ember természete és helye a világban, Budapest 1976., PLESSNER, H., Die Stufen des Organischen und der Mensch, Einleitung in die philosophische Anthropologie, Berlin 1928.

${ }^{27}$ Vö. CORETH, Was ist der Mensch?, 157. Arisztotelész már ezen a módon gondolja el a test és a lélek összefüggését. A test szerinte csak a lelken keresztül birtokolhatja önmaga valóságát. Tulajdonképpen értelmetlenség azt kérdezni, hogy a test és lélek egyek-e. Ez olyan, mintha arról érdeklődnénk, hogy a viasz és annak alakja egyek-e. Hiszen az anyagi létezők mindig a formájukon keresztül lesznek konkrétak. Erre hozza még a megértéshez példaként azt, ha a szem egy önálló élólény lenne, akkor e szem látóereje, látóképessége lenne a szem lelke, a szem pedig maga, mint testi szerv lenne a test.
} 
takozásának elve az emberi szellemi lélek, ami egyben a tulajdonképpeni emberi, a személyes, szellemi létünk megvalósulásának is az elve.

\section{Irodalomjegyzék}

Ambrus G. (2007): Analitikus filozófia, In: (szerk. Boros Gábor), Filozófia, Budapest, Akadémiai Kiadó, 1065-1145.

Coreth E. (1980): Was ist der Mensch? Grundzüge einer philosophischen Anthropologie, Innsbruck-Wien-München, Herder.

Descartes R. (1994): Elmélkedések az első filozófiáról, Budapest, Atlantisz.

Pápai Enciklika (1998): Fides et ratio.

Hirschberger J. (1991) Geschichte der Philosophie, Band II, Freiburg-Basel-Wien, Herder.

Huoranszki F. (2001): Modern metafizika, Budapest, Osiris.

Köhler P. (2004): Geh mir aus der Sonne! Anekdoten über Philosophen und andere Denker, Stuttgart, Philipp Reclam jun.

Leibniz G. W. (1986): A természet és a kegyelem ésszerúen megalapozott elvei, Válogatott filozófiai írások, Budapest, Európa.

Leibniz G. W. (1930): Újabb vizsgálódások az emberi értelemról, Budapest, Magyar Tudományos Akadémia.

Pascal B. (2005): Gondolatok, Szeged, Lazi Könyvkiadó.

Spinoza B. (1969): Etika, Budapest, Helikon.

Tốzsér J. (2009): Metafizika, Budapest, Akadémiai Kiadó.

Tôzsér J. - Ullmann T. (2009): A "lélek" fogalma a 20. századi filozófiában, Mentofaktúra folyóirat - filozófia és coaching 1. http://www.mentofaktura.hu/1szam/ tozser1.pdf.

Weischedel W. (1983): Der Gott der Philosophen, Darmstadt, Wissenschaftliche Buchgesellschaft.

Vincze Krisztián teológus, fôiskolai adjunktus 